\title{
The Role of BPD in Preparation of APBD to Realize Village Autonomy
}

\section{Muhammad Ali Maskun*) and Siti Rodhiyah Dwi Istinah**)}

${ }^{*}$ Student of Master of Law Program, Faculty of Law Universitas Islam Sultan Agung and Bank Mandiri Legal Staff email alimaskun168@gmail.com

${ }^{* *}$ ) Faculty of Law Universitas Islam Sultan Agung

\begin{abstract}
.
Destination from this research, namely: To know and analyze the procedures for the preparation of the Village Budget (APBD) in the framework of realizing village autonomy. To find out and analyze the role of the Village Consultative Body (BPD) in Budget Formulationm Village Income and Expenditure (APBD) to realize village autonomy. To find out and analyze obstacles and solutions to the role of the Village Consultative Body (BPD) in the Preparation of the Village Revenue and Expenditure Budget (APBD) to realize village autonomy. The method used by researchers is juridical sociological approach to law and the specifications in this research are descriptive. Based on the results of that research The Village Income and Expenditure Budget (APBD) Preparation Procedure in the framework of realizing village autonomy is as follows: The activity implementer submits activity budget proposals to the village secretary based on the stipulated RKP's village; The Village Secretary prepares the Draft Village Regulation on APB's village (RAPB's village) and submits it to the Village Head. The role of the Village Consultative Body (BPD) in the Preparation of the Village Revenue and Expenditure Budget (APBD) to realize village autonomy, among others, is to convey the idea of managing village funds as a form of collecting community aspirations as determining priorities for implementing village fund management with consideration of the village head. The process of planning the Village Fund Budget management during village meetings, low community self-help, delays in disbursement of village funds, changes in nominal APB's village funds received and a new Regent regulation. Efforts to overcome this problem include the Blerong village government with an agreement with the Village Consultative Body to disseminate information on the importance of community self-help, then use Village Original Income funds, and Fund Less Channels, whose implementation is in accordance with the provisions of the applicable legislation.
\end{abstract}

Keywords: Role; Village Consultative; Village Revenue and Expenditure Budget; Village Autonomy.

\section{Introduction}

The Republic of Indonesia as a Unitary State adheres to the principle of decentralization in administering government by providing opportunities and flexibility for regions to carry out regional autonomy. ${ }^{1}$ In carrying out Village

1 Widjaja, HAW. (2012). Otonomi Desa Merupakan otonomi yang Asli. Bulat dan Utuh, cet. ke-6 Jakarta: Rajawali Pers. p. 1. 
Government administration, the Village can carry out legal actions both in public law and civil law, own assets, property and buildings and can be prosecuted and sued in court. In addition, government administration and Village development must be able to accommodate the aspirations of the community, realizing the active role of the community to participate in being responsible for the development of life together as fellow villagers. ${ }^{2}$

In the framework of implementing regional autonomy in Indonesia, it is stated in Article 18 of the 1945 Constitution, among others, that the Unitary State of the Republic of Indonesia is divided into provincial regions, the province is divided into regencies and cities, each of which has a government region, which is regulated by law. Whereas in the above explanation, the State of Indonesia is an eenheid staat, then Indonesia will not have areas in its environment that are staat in nature. ${ }^{3}$

Also stipulated in the regional autonomy law, namely Act No. 23 of 2014 concerning the Third Amendment to Act No. 32 of 2004 concerning Regional Government. The implementation of regional autonomy according to this law is the right, authority and obligation of the autonomous region to regulate and manage government affairs and the interests of the local community in accordance with regional laws and regulations. Regional authority to regulate their regions includes the authority to manage the finances of their respective regions. This law has provided a formal generation and opened space for villages to open up independence (autonomy), a space for the spirit of locality and village autonomy.

The Village Consultative Body (BPD) is an institution that embodies democracy in the implementation of village governance. The BPD can be considered the "parliament" of the village. BPD is a new institution in the village during the era of regional autonomy in Indonesia which was formed based on a law.

In carrying out the aforementioned government affairs, the government organizes itself or can delegate part of government affairs to government apparatus or government representatives in the regions or can assign to local governments and or village governments. ${ }^{4}$

The objectives of this study are: To find out and analyze the procedures for Village Revenue and Expenditure Budget Formulation (APBD) in the framework of realizing village autonomy; To find out and analyze the role of the Village Consultative Body (BPD) in the preparation of the Village Revenue and Expenditure Budget (APBD) to realize village autonomy; To identify and analyze barriers and solutions the role of the Village Consultative Body (BPD) in the preparation of the Village Revenue and Expenditure Budget (APBD) to realize village autonomy.

\footnotetext{
2 Kaputra et.al, Iswan. (dkk). (2013). Dampak Otonomi Daerah Di Indonesia. Jakarta: Yayasan Pustaka Obor Indonesia. p. 70-71

${ }^{3}$ Sudarsono. (2009). Kamus Hukum. cet. ke-6. Jakarta: Rineka Cipta. p. 109, 454.

${ }^{4}$ Huda, Ni'matul. (2012). Hukum Tata Negara. cet. ke-6. Jakarta: Rajawali Press. p. 363
} 


\section{Research methods}

The approach method used by the author in this study is a sociological juridical approach. The type of research used by the writer in this research is descriptive research. The sources and types of data in this study are secondary data obtained from literature studies related to the theory of the role and authority of the village.

\section{Results and Discussion}

\subsection{Village Income and Expenditure Budget (APBD) Preparation Procedures in the Framework of Realizing Village Autonomy}

According to Kaufman and Thoha, the government's task is to serve and organize society. The duty of service emphasizes the efforts to prioritize the public interest, simplifies public affairs, shortens the time for the implementation of public affairs and provides satisfaction to the public, while the task of regulating emphasizes the power or power inherent in bureaucratic positions. ${ }^{5}$

The essence of the main tasks of government can be summarized into three essential functions, namely: Service, empowerment, and development. Service will produce justice in society, empowerment will promote independence in society and development will create prosperity in society. ${ }^{6}$ Siagian argues that there are four main functions of government, namely: First, maintaining order and peace (maintenance of peace and order), Second, defense and security, Third, diplomatic, and Fourth, taxation. ${ }^{7}$

Management of village funds is expected to improve community welfare. A prosperous society will make the country strong and able to compete with other countries. Welfare is a condition of fulfilling the needs of an increasingly quality life, therefore welfare is the main value that every human being strives to realize. Village funds are an important factor in creating welfare. Therefore, it must be managed properly in order to be effective and efficient. ${ }^{8}$

The concessions given by the central government to village governments to manage the Village Funds bring many benefits, especially in development in villages. However, if this authority is not balanced with awareness of the law, it will cause difficulties for village officials, as well as cause losses for villagers. Even though the village is the embryo of the formation of society and government in Indonesia. Long before modern nations were formed, social groups such as villages or indigenous peoples and so on had become an important part of a state structure.

Therefore, the management of village funds must be in accordance with existing regulations so that the objectives of the Village Fund can be right on target and do not cause legal proceedings. Village Funds are funds sourced from the state

\footnotetext{
${ }^{5}$ Miftah, Thoha. (2003). Birokrasi dan Politik di Indonesia. Jakarta: Raja Grafindo Persada. p. 71

6 Makna Pemerintahan. (2000). Tinjauan dari Segi Etika dan Kepemimpinan. Jakarta: Mutiara Sumber Widya. p. 59

7 Sondang, Siagian, P. (1987). Administrasi Pembangunan. Jakarta: Haji Masagung. p. 101

8 Winarni, Endah Dwi. Pertanggungjawaban Pidana Dalam Pengelolaan Dana Desa Berdasarkan PP Nomor 8 Tahun 2016 (Studi Kasus Di Desa Srikaton KeHead of districtan Jaken Kabupaten Pati), Jurnal Daulat Hukum Vol. 1. No. 1 March 2018 ISSN: 2614-560X. Unissula
} 
revenue and expenditure budget allocated to villages that are transferred through the district/city regional income and expenditure budget and are used to finance government administration, development implementation, development, community development and community empowerment. ${ }^{9}$

The Village Revenue and Expenditure Budget (APB's village) is an important instrument that is very decisive in the context of the realization of good governance and the implementation of development at the village level. Good governance, among others, is measured by the formulation process and accountability of the APB's village. Understanding the process at all stages of APB's village management (preparation, implementation, accountability) gives meaning to the village governance model itself. 10

The procedure for preparing the Village Budget (APBD) in the framework of realizing village autonomy is as follows:

- The activity implementer submits the activity budget proposal to the village secretary based on the stipulated RKP's village;

- The Village Secretary prepares the Village Regulation Draft on APB's village (RAPB's village) and submits it to the Village Head;

- The Village Head then conveyed to the Village Consultative Body (BPD) to be discussed and mutually agreed upon. The Draft Village Regulation on APB's village is mutually agreed upon no later than October of the current year between the Village Head and the BPD;

- The Draft Village Regulation regarding APB's village that has been mutually agreed upon as subsequently submitted by the Village Head to the Regent through the Head of district or other designation no later than 3 days after it was agreed to be evaluated;

- The Regent/Mayor determines the evaluation results of the Draft APB's village within 20 working days from the receipt of the draft village rules on APB's village.

\subsection{The Role of the Village Consultative Body (BPD) in the Preparation of the Village Revenue and Expenditure Budget (APBD) to realize village autonomy}

The Village Consultative Body or abbreviated as BPD is an institution in the village that has strategic tasks and functions for the smooth running of village development activities, especially when it is associated with the condition of rural communities who have very high dynamics and life in democracy. In addition, the presence of the BPD has provided a very positive room for movement in the configuration (form) of democracy, especially for rural communities by channeling their political aspirations. As an independent institution/social institution in the village administration system, BPD as a legislative body and as a village parliament brings new nuances in mobilizing the participation of the village people in democratic life.

\footnotetext{
${ }^{9}$ Act of the Republic of Indonesia Number 6 of 2014 and Government Regulation of the Republic of Indonesia of 2016 concerning Villages

10 http://Berdesa.com/Alur-dan peran-dalampenyusunan APBDesa.
} 
The 1945 Constitution is the highest law in Indonesia. From 1999 to 2002 there have been four stages of change carried out democratically, constitutionally and institutionally by the MPR. Arrangements that have undergone changes include Article 18 concerning regional government administration arrangements. The implementation of the provisions of Article 18 of the 1945 State Constitution of the Republic of Indonesia is currently carried out with Act No. 23 of 2014 concerning Regional Government as the basis for the political reference of regional autonomy law in Indonesia. Regardless of the extent of the autonomy granted to the Regions, the final responsibility for the administration of the Regional Government will remain in the hands of the Central Government. Public Service Guarantee includes principles in the delivery of public services. The scope of public services includes public goods services and public services as well as administrative services. Public Service Management, Local Government is obliged to build public service management by referring to the principles of public services. The principles of governance in Islamic perspective can be traced in the Qur'an and Hadith, including power as trust, deliberation, upholding legal certainty and justice, leadership, responsibility of leaders, relationships between leaders and those led based on brotherhood and mutual love. ${ }^{11}$

One thing that is hard to deny is that the excessive use of freedom of action can have a negative impact, namely the government can tend to use more power in carrying out its duties which in turn can be dragged into the state of power (machtsstaat). Therefore, to eliminate the actions of local governments in implementing them (political will) so that they are not trapped in the category of State of Power (machtsstaat), these actions must be packaged in legal products in the form of regional regulations which in turn can be categorized as a rule of law (rechtsstaat). Other impacts of the excessive use of power by local governments in carrying out their duties can result in negative actions, including: 12

The role of the Village Consultative Body (BPD) in the formulation of the Village Income and Expenditure Budget (APBD) to realize village autonomy, among others, is to convey the idea of managing village funds as a form of collecting community aspirations as determining priorities for implementing village fund management with the consideration of the village head. Supervision and monitoring in managing village funds is carried out by BPD directly and goes according to what is expected with the head and village apparatus, as well as community groups from start to finish. Evaluation of village fund management is carried out by BPD as the executor of duties and obligations so that the implementation of village fund management can run well and as expected.

\subsection{Barriers and solutions to the role of the Village Consultative Body (BPD) in the Preparation of the Village Revenue and Expenditure Budget (APBD) to realize village autonomy}

\footnotetext{
11 Kusriyah, Sri. Politik Hukum Penyelenggaraan Otonomi Daerah dalam Perspektif Negara Kesatuan Republik Indonesia, Jurnal Pembaharuan Hukum Volume III No. 1 January - April 2016

12 Sulistiyo, Iwan. Widayati, Sri Kusriyah, Implementasi Asas Keterbukaan Dalam Proses Pembentukan Peraturan Daerah Dalam Rangka Otonomi Daerah Di Kabupaten Kendal. Jurnal Daulat Hukum Vol. 1. No. 1 March 2018 ISSN: 2614-560X. Unissula.
} 
In Indonesia, use it in realizing Good Governance according to Law No. 30 of 2014 concerning Government Administration. The general explanation also explains that Good Governance or it can be abbreviated as AUPB will continue to develop, in accordance with the development and dynamics in society in a rule of law. This law has become the legal basis for government administration in improving Good governance.

The form of good governance according to LAN is the implementation of a state government that is solid and responsible, as well as effective and efficient, by maintaining constructive interactive synergies between the domains of the state, private sector, and society. According to UNDP (United Nations for Development Program) in Grindle (1997: 3), good governance can be interpreted as: ${ }^{13}$

"... good governance among other things, participatory, transparent and accountable. It is also objective and equitable and it promotes the rule of law. Good governance ensures that political, social and economic priorities are based on broad consensus able are heard in decision making over the allocation of development resources."

The obstacles and solutions to the role of the Village Consultative Body (BPD) in the Preparation of the Village Revenue and Expenditure Budget (APBD) to realize village autonomy include:

- There are budget limitations in the APB's village implementation process,

Efforts to overcome this problem of budget limitations, the village government uses village funds that are not channeled enough, PA's village funds and borrowing material partners to assist the process of village development programs that have been agreed upon during village deliberations, because this budget limitation greatly affects village development, the work plan program not yet realized this year will be done in the following year.

- The planning process for the management of the Village Fund Budget during village meetings.

To overcome this problem, by conducting village deliberations attended by members of the community including PKK members, RT heads and RW heads as well as other members of the general public. With routine village deliberation activities, there will be trust from the community in the village government in managing ADD funds and it is hoped that it will not become an obstacle in the planning process for managing the Village Fund Budget at the next village deliberation.

13 Purnama, Eko Saka. Dkk. (2012). Membuka Informasi Menuju Good Governance. Jakarta: Universitas Indonesia (UI-Press). p. 12. 
- Low community self-help.

Efforts to overcome the problem of low community self-help were carried out by the village government to the village community, which is carried out during the village deliberations, the importance of community self-help has an impact on the management of village funds budget funds.

- Constraints on delays in disbursing Village Funds.

To solve this problem, the Village Government borrows material partners in the village, this is also considered because it is also to increase the income of Blerong villagers as well.

- Constraints on changes in nominal APB's village funds received.

Efforts to solve this problem, the village government in meeting the needs of village administration and village development, namely by using village funds that are less channeled and PA's village funds that have been agreed with the BPD.

\section{Closing}

The Village Income and Expenditure Budget (APBD) Preparation Procedure in the framework of realizing village autonomy is as follows: The activity implementer submits activity budget proposals to the village secretary based on the stipulated RKP's village; The Village Secretary prepares the Draft Village Regulation on APB's village (RAPB's village) and submits it to the Village Head.

The role of the Village Consultative Body (BPD) in the formulation of the Village Income and Expenditure Budget (APBD) to realize village autonomy, among others, is to convey the idea of managing village funds as a form of collecting community aspirations as determining priorities for implementing village fund management with the consideration of the village head.

Obstacles include budget limitations, the planning process for Village Fund Budget management during village meetings, low community self-help, delays in disbursing village funds, changes to the nominal value of APB's village funds received and the existence of a new Regent regulation. Efforts to overcome this problem include the Blerong village government with an agreement with the Village Consultative Body to disseminate information on the importance of community self-help, then use Village Original Income funds, and Fund Less Channels, whose implementation is in accordance with the provisions of the applicable legislation.

It is necessary to establish more technical guidelines related to the format of village financial management from planning to reporting and accountability. This is so that the village government will find it easier to prepare plans for implementing village programs and be able to report on the implementation of village development in an accountable, transparent and participatory manner. It is recommended that the APB's village fund management scheme be adjusted to the condition of the existing human resources in the area so that these funds can be used properly and are right on target. 


\section{References}

\section{Journals}

[1] Kusriyah, Sri. Politik Hukum Penyelenggaraan Otonomi Daerah dalam Perspektif Negara Kesatuan Republik Indonesia, Jurnal Pembaharuan Hukum Volume III No. 1 January - April 2016

[2] Sulistiyo, Iwan. Widayati, Sri Kusriyah, Implementasi Asas Keterbukaan Dalam Proses Pembentukan Peraturan Daerah Dalam Rangka Otonomi Daerah Di Kabupaten Kendal. Jurnal Daulat Hukum Vol. 1. No. 1 March 2018 ISSN: 2614560X. Unissula

[3] Winarni, Endah Dwi. Pertanggungjawaban Pidana Dalam Pengelolaan Dana Desa Berdasarkan PP Nomor 8 Tahun 2016 (Studi Kasus Di Desa Srikaton KeHead of districtan Jaken Kabupaten Pati), Jurnal Daulat Hukum Vol. 1. No. 1 March 2018 ISSN: 2614-560X. Unissula

\section{Books}

[1] Huda, Ni'matul. (2012). Hukum Tata Negara. cet. ke-6. Jakarta: Rajawali Press.

[2] Kaputra et.al, Iswan. (dkk). (2013). Dampak Otonomi Daerah Di Indonesia. Jakarta: Yayasan Pustaka Obor Indonesia.

[3] Makna Pemerintahan. (2000). Tinjauan dari Segi Etika dan Kepemimpinan. Jakarta: Mutiara Sumber Widya.

[4] Miftah, Thoha. (2003). Birokrasi dan Politik di Indonesia. Jakarta: Raja Grafindo Persada.

[5] Purnama, Eko Saka. Dkk. (2012). Membuka Informasi Menuju Good Governance. Jakarta: Universitas Indonesia (UI-Press).

[6] Sondang, Siagian, P. (1987). Administrasi Pembangunan. Jakarta: Haji Masagung.

[7] Sudarsono. (2009). Kamus Hukum. cet. ke-6. Jakarta: Rineka Cipta.

[8] Widjaja, HAW. (2012). Otonomi Desa Merupakan otonomi yang Asli. Bulat dan Utuh, cet. ke-6 Jakarta: Rajawali Pers.

\section{Internet}

[1] http://Berdesa.com/Alur-dan peran-dalampenyusunan APB's village.

\section{Regulation}

[1] Act of the Republic of Indonesia Number 6 of 2014 and Government Regulation of the Republic of Indonesia of 2016 concerning Villages. 